\title{
Claude Bissell's Idea of the University
}

\author{
DANIEL WALLACE LANG*
}

During the last two decades few institutions have been as much in the forefront of public affairs as the university. Although specific issues having to do with higher education have changed from time to time, debates on those issues almost always have included references to an idea of the university. Both critics and defenders of the university have been wont to invoke the traditions and ideals of the university in arguing for their varying points of view. The freedom and frequency with which the idea or ideal of the university is injected into public discourse suggest that there is a general agreement and understanding about what the university ideally is or should be. But issues have remained unresolved and the debates have continued. Perhaps the idea of the university is not as well understood as it seems to be; perhaps there is no coherent idea at all.

The objective of this essay is to describe and analyse the ideas of one person who has said and written more about the university than any other Canadian. He is Claude Thomas Bissell, president of Carleton University from 1956 to 1958 and the University of Toronto from 1958 to 1971. Many of his ideas about the university are thought-provoking, some are unique, and all of them taken together constitute a definition of the university idea within Canadian society.

Before considering Bissell's ideas about the university, a brief comment about the methodology of our approach in this discussion is in order.

Western society is indebted to John Henry Cardinal Newman ${ }^{1}$ for having first suggested that there was an "idea of the university." Despite the gratitude due him, the ramifications of Newman's approach are as complicating as they are illuminating. Like many foundations of social and intellectual history, Newman's description of what, in his opinion, the ideal university should be came, over time, to be regarded as what the idea of the university in fact was. Newman's idea for a university became the idea of The University. More important, Western thought has come to assume that the idea of the university preceded the reality of the university, or, stated in other words, that the abstraction preceded the institution. Philosophically this is a Platonic attitude and historically it is very Christian. That there were and are deviations from the ideal does not deny the ideal's existence.

*Formerly Associate Dean at Wesleyan University, Mr. Lang currently is in his final year of Ph.D. studies at the University of Toronto.

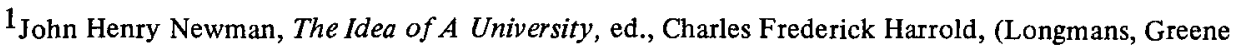
\& Co., New York, 1947). 
The complication caused by Newman's approach to the matter of the university is that, because the approach has become part of Western society's intellectual perspective, we assume that all persons engaging in discourse about the university begin with the premise that there is or should be an idea of the university. (This is not to say that the idea of the university necessarily is Newman's.) It is for this reason that most statements about the university are prescriptive rather than descriptive, and theoretical rather than practical.

But the student of social and intellectual history knows that some institutions are not the products of deliberate creation, but of evolution, and for some institutionalization precedes abstraction. Until recently, this has been the perspective of most modern historians. Thus we talk about the "roots" of ideas and the "beginnings" of institutions.

What has all of this to do with our approach to Claude Bissell's ideas about the university? In the first - and most obvious - place, it is important to ask whether or not Bissell subscribed to the belief that there is or should be an ideal of the university. Second, were this ideal to be assumed to exist, was it in Bissell's view an immutable social foundation or was it malleable and subject to society's changing demands and conditions? And, finally, did Bissell take a perspective which assumed the institutionalization of the university or the idea of the university?

Although Bissell refers often to Newman, he rarely speaks of an idea of the university - Newman's or anyone else's. More significantly, Bissell has never made an integrated and fully developed statement about the university as a whole. His statements about the university are narrowly circumscribed and tend to be very specific in focussing on different aspects of the university or of its relations with other parts of society. Although many in number, Bissell's statements about the university are very few in kind. They consist of nearly one hundred addresses to all sorts of audiences and of his reports made as president of two universities. There are only a handful of exceptions to his comments about the university being made in the form of a public address or a presidential report. Even his most well-known statement about the university, The Strength of the University, is an anthology of public addresses. No criticism of Bissell is implied in this description of his comments about the university; the point to be noted is the nature of the source of information available to a discussion of Bissell's ideas.

Judging from the texts of his speeches, Bissell was a sensitive and considerate public speaker. His addresses with few exceptions were written and delivered with his immediate audience in mind. While this no doubt was an asset to Bissell and to his audience, it is something of a liability to a discussion seeking to identify and define Bissell's basic ideas and opinions about the university and its component parts. Emphases change throughout his addresses and reports. This seems natural for a man who occupied a central position in the university world at a time when that world was fraught with tension and conflict. Nevertheless, the task of sifting through the subjective and specific to isolate the objective and general is a difficult one and is one that simply must be done if at least some unitary understanding is to be achieved.

Whether by circumstance or design, Claude Bissell never made an all encompassing, unitary, and detailed statement about the idea of the university as did Newman or Jaspers. ${ }^{2}$ It would seem, given his keen awareness of his role, that his mode of expression was intended and deliberate. Although it is our intention to describe and analyse 
Bissell's idea of the university, we must consider the possibility that the existence of a formal and inclusive idea may be entirely artificial in the sense that it may be crystalline only in this discussion and not in the thought of Claude Bissell. In other words, the idea which we attribute to Bissell may be synthetic rather than natural.

Bissell himself was not unaware of the perspective of the podium from which he wrote and spoke. In beginning an address about higher education in Ontario he said. "This lecture, in short, is neither historical nor academic but didactic and political. I think you will agree that this is the proper genre for a university administrator, especially if he finds himself close to the centre of events." Bissell surely was both an administrator and one who was close to the centre.

Bissell recognized that he wrote and spoke as a university president. In synthesizing his statements and opinions, we must be aware of the context in which they were made and of the fact that this context of ten changed. Bissell described the implications of context well in a speech which he delivered in Edmonton after having stepped-down from the presidency of the University of Toronto.

There are some advantages and some disadvantages in asking an Ex-President of a University to give a public speech ... The advantage, theoretically, at least, is that one is in a position to speak with frankness and objectivity. The disadvantage is ... that one speaks without the sobriety induced by a fear of consequence.

As we can see from this statement, Bissell himself knew that as president he may not always have been able to be as frank and objective as he otherwise might have chosen to be. Perspective and context, thus, are in effect filters through which Bissell's comments must be viewed as we analyse and organize them in attempting to discover and define his idea of the university. In functional terms this means that our emphases and organizations of material may not always be the same as Bissell's, and the standard by which we decide to include or exclude specific information may not coincide with that which he himself might have chosen to employ.

These, then, are the framework, the means, and the method which comprise the rationale for this discussion's approach to Claude Bissell's ideas about the university. We turn now to those ideas.

In 1965 at Vancouver, Claude Bissell delivered an address to which he gave the title "Characteristics of a Great University." Because it is not unreasonable to assume that a great university more closely approximates the ideal of the university than do more common colleges and universities, we may presume that in this address Bissell's point of reference is theoretical rather than practical. The characteristics which he attributed to the great university are four in number and provide both a useful framework for our further discussion and an insight into Bissell's opinions about the basic components of the university and (assuming its existence) the idea of the university.

The first of the four characteristics is that the great university should be "a stronghold of scholarship in the pure theoretical subjects that lie at the basis of any expansion

${ }^{2}$ Karl Jaspers, The Idea of the University, trans., H. Reiche and H. Vanderschmidt, (Peter Owen, London, 1965). 
of knowledge." That the university should be a bastion of scholarship is an element which one would expect to be part of almost any prescription for a university. But Bissell's statement contains more than the common argument for the pursuit of scholarship; it suggests a definition of scholarship itself and this definition is not common or obvious.

Bissell included these scholastic disciplines among those which he considered basic and theoretical: physics, biology, chemistry, mathematics, political science, economics, philosophy, literature, and history. In an earlier speech he had added to this list geology, sociology, anthropology, geography, and psychology; he called the entire group "the great intellectual disciplines." He discriminated further within this group and allocated political science, mathematics, biology, chemistry, geology, physics, literature, philosophy, and history to a special group which he considered more important and central. In the great university these were the subjects which were strongest and which attracted the best students.

This cataloguing of academic disciplines did not, in Bissell's mind, relegate professional and applied studies to entirely subordinate positions. Those which relied on theoretical knowledge occupied a high place in his estimation. The university's responsibility to professional studies, however, was not total. Bissell would have the great university limit its commitment to professional studies to training leaders, undertaking research, and preparing university-level teachers.

What, then, was the status of subjects not included on Bissell's list of those which he considered centrally essential to the university? He did not believe that these omitted subjects were totally without merit or value. He once described their situation in this way: "The trouble with so-called auxiliary subjects is not that they are entirely unimportant, but that they consume an amount of time and attention that is disproportionate to their educational value." This statement offers evidence that Bissell's categorization of subjects is based not only on an intellectual foundation, but also on an educational one. There are two important but subtle points to be made within this context.

The first is that Bissell apparently considered knowledge - at least, knowledge in a formal and organized sense - to be of several types and that some types of knowledge were more appropriate than others in an educational process. In his Opening Address at the University of Toronto in 1968 he explained that the primary purpose of the university was "the preservation, dissemination, and expansion of knowledge, and knowledge of a particular kind, knowledge that can be expressed in words or symbols." The concept of the university as an instrument for nurturing knowledge, adding to it, and transferring it from generation to generation is one which is understood and accepted widely. Bissell, however, has added an important qualification to this concept by saying that the university should concern itself with knowledge which "can be expressed in words or symbols." This understanding and definition of knowledge as it pertains to the university amplifies and adds clarity to the manner in which Bissell categorized the various academic disciplines and subjects. At least one part of the standard by which he differentiated among subjects was based on the modes of expression inherent in those subjects.

This understanding of the varieties of knowledge which are appropriate for inclusion

*In another instance Bissell substituted "numbers" in place of "symbols." 
in the university's curriculum immediately raises questions about relations between the arts (music, theatre, and fine art) and the university. Defining this relationship usually results in equivocation and complexity, especially for the university, since it tends to be more sensitive and appreciative of the arts than do some other sectors of society. Because of this proclivity towards equivocation, discussions about the roles of the university sometimes ignore or skirt questions about how the arts relate to the university. Claude Bissell, on the other hand, addressed this question directly.

The university, Bissell argued, should be a patron of the arts so that students will be reminded "constantly of the variety and beauty of the world in which they live." As we shall observe later, Bissell believed that a special type of campus environment is essential to the proper functioning of the university. However, Bissell did not advocate that the university wholly incorporate the arts into its academic programs. In explaining why the university had not been active in the arts, he noted:

There is an inherent conflict between those who use words as their means of communication and those who use sound, colour, and form. Artists, even if their medium is words, are not famous for articulateness. Indeed, articulateness - clarity, precision, and ease in the use of words - is often looked upon by artists as a mark of superficiality, as an attempt to oversimplify and vulgarize.

It is not entirely clear whether in making this comment Bissell was stating his own belief or describing only what he considered to be the attitude prevailing in the university generally. Given the context within the address in which he made this remark, Bissell surely intended the latter, but it also seems likely that he subscribed to this attitude himself. The most salient evidence of this likelihood is Bissell's focus on modes of expression and, subsequently, on words not being the mode employed - or, even, respected by artists. This is exactly the standard by which he differentiated among varieties of knowledge.

Not as salient, but perhaps more persuasive is Bissell's contention that, with the exception of music, training in the arts should not be undertaken by the university. He excepted music for reason of historical tradition; music being one component of the medieval quadrivium. Were this historical tradition to have been absent, one might assume reasonably that Bissell would not have made this exception. He did believe, however, that the history and philosophy of the arts are legitimate subjects for the university's curriculum and are to be encouraged.

A final note which suggests that Bissell considered the arts to be inappropriate subjects for the university is his belief that potentially successful artists often were incapable of meeting university entrance requirements; Bissell refused to countenance any compromise which might have caused admissions standards to deteriorate.

The second important and subtle point to arise from the intellectual and educational foundations which support Bissell's categorization of subjects is, simply, that there are in fact educational foundations. The potential applications of different varieties of knowledge were as important to Bissell as the inherent intellectual qualities of those varieties. "Knowledge," according to Bissell, "is an explosive (or implosive) force. . .." The importance of this perspective is that it focuses on the implications of knowledge and, 
in a narrower sense, of academic subjects. These implications have two sources: the nature of knowledge (or types of knowledge) and the ways in which knowledge can be applied or transferred.

Bissell ascribed two kinds of power to knowledge and, subsequently, to the university as the custodian of knowledge. These are the power of compulsion and the power of persuasion. Bissell described these powers thus:

The power of compulsion fastens upon means to secure ends that are taken for granted. The end, in its simplest and crudest form, is to create more of what we already have.

The power of persuasion, on the other hand, is concerned about ends. It asks the simple, devastating questions. What are the real satisfactions of man?

The significance of these descriptions apropos of this discussion is that they suggest that it is possible to discriminate among types of knowledge or on the basis of what knowledge does as well as on what knowledge is. In making this distinction, Bissell assigned these two facets of knowledge to equal positions of importance. This balance was, Bissell believed, crucial to the university. He described it in this way:

There are two main ones [balances] - first, the balance between the humanities and social sciences on the one hand and the physical and natural sciences on the other. In the first instance, we refer to the distinction between theoretical knowledge and the strategy of application, and in the second, between the study and analysis of human values on the one hand and the study of physical reality on the other.

The ways in which knowledge might be applied were, as the foregoing quotation explains, one of two major components of the university's organization and role. In the end, the ways in which knowledge was applied could justify the university's social role as the provider and custodian of liberal education. This justification was, in Bissell's judgment, that a liberal education "creates a society in which from time to time individuals make discoveries, or enunciate ideas that help all of us to live more securely and wisely." "The ivory tower," Bissell once said, "might well be the best launching pad for missiles, whether benign or aggressive. Theoretical knowledge entered into a storehouse from which others could draw for practical improvements."

The concern for balance is central to Claude Bissell's idea about the university as an institution and is representative of the subtlety and complexity of that idea. The balances within the sphere of scholarship are between individual subjects, varieties of knowledge, and the uses and applications of knowledge. Although his catalogue of subjects is, at least in part hierarchical, there is a point beyond which Bissell would not make hierarchical distinctions. This point is defined by the division among subjects which circumscribes that group of disciplines which he considered to be of greatest importance and significance. One may recall that this group included political science, mathematics, biology, chemistry, geology, physics, literature, history, and philosophy. Bissell insisted that discrimination within this group was impossible and that the university must pursue a policy by which parity will be preserved among them. 
This devotion to parity was due partly to the nature of knowledge and partly to the role of the university. With respect to the former, Bissell believed that there was an organic inter-relationship among the primary subjects of the arts and sciences. Assigning these subjects to a primary position, Bissell maintained, was an assertion of a "belief in the unity of knowledge." Regarding the latter, Bissell felt that the university as a matter of policy must maintain the parity among the primary subjects as defined by his categorization. He made this amply clear in these two statements:

The preservation of parity of strength throughout the University is the guiding principle of our plans for the future .... The parity of strength is not only the soundest principle for the organization of a university, but it is also a means of encouraging easy communication between various divisions of the university.

and

As one looks back over the history of the University of Toronto, the clarifying principle that emerges is concern for parity among the various branches of learning.

By discussing the disciplines in which university scholarship should be undertaken, we have addressed one part of Bissell's first characteristic of the great university. The other part is scholarship itself. Unlike many who observe and comment on the university, Claude Bissell took care to use words precisely in describing the university. He knew clearly what he meant when he spoke of scholarship. In his installation address at the University of Toronto he defined scholarship in this way:

Scholarship, I would contend, is a more comprehensive and satisfying word than research. Research often involves simply isolating a problem and solving it by patient devotion. But scholarship is a product not only of industry and exactitude, but also of imagination. The scholar may not make any discernible addition to the pile of facts, but he may provide the synthesizing concept, the sudden illumination that seems to leap beyond the available evidence. It is this kind of scholarship that produces the proper intellectual environment for a university.

In terms of the often stated dichotomy between teaching and research, Bissell's description of scholarship implies that research is closer to the core of scholarly activity in the university than is teaching. He addressed this matter more directly in his first report as president of Carleton in which he made these remarks:

It is worth asking ourselves just what the university name means. It means, first of all, that an institution is engaged in instruction in more than one major division of knowledge .... But the second, and more basic [italics mine], criterion is that an institution is seriously concerned with work of a senior nature, and that it accordingly devote a significant proportion of its resources to research and graduate work.

It seems reasonable to conclude that in Bissell's mind scholarship as a hallmark of the great university refers mainly to research which expands and elucidates knowledge, and 
that instruction is a necessary, but not primary, ingredient in university scholarship. This is not to suggest that instruction is not vitally important to the great university as described by characteristics other than that of scholarship.

There is one other dimension of Bissell's definition of scholarship as a characteristic of the great university. And this dimension has to do with quality. Scholarship in the great university could be nothing but first-rate in all respects. In referring to his predecessors in the office of president at the University of Toronto, Bissell observed:

The common quality that characterizes all the men who have given leadership to this university has been an awareness of the importance of scholarship. They speak with one voice in declaring that the university must be the custodian of the excellent. Excellence is not a virtue that flourishes in isolation. A first class staff needs a first class student body, and by the same token, a first class student body rapidly becomes dissatisfied with a second class staff.

Bissell always insisted on excellence and the maintenance of high standards. Thus, to be great, the university must ensure that the scholarship undertaken within it be of the highest quality and must not brook any compromises of this quality.

In summary, Bissell's first characteristic of the great university is scholarship in the arts and sciences which meets standards of excellence, which is oriented predominantly towards research, and which respects the organic unity and parity among the primary disciplines.

The second characteristic which Bissell attributed to the great university is even more deeply concerned with a sense of balance in the university. The second characteristic embodies a balance between graduate and undergraduate studies. According to Bissell, the great university would have graduate and undergraduate programs which both were fully developed and which both maintained standards of excellence.

On its face this is a straightforward and somewhat unremarkable statement. However, if it is regarded as a rubric under which the other fundamental aspects of the university are subsumed, it has a much more elaborate and significant meaning. If excellence and balance are to be realized in the university, there are direct and definite implications for students, teachers, and university policies about research, admissions, curriculum, and teaching.

Claude Bissell held strong opinions about the role of the student in the university. For a university president in the 1950's and 1960's he was unusually interested in and concerned about admissions standards and procedures. There seems to have been no doubt in Bissell's mind that overall quality within the university required that standards at the point of access to the university be strictly maintained at the highest possible level. This attitude suggested to some persons that Bissell was an elitist. In fact, at least one person claims that Bissell once admitted to him that "his conception of society was elitist. And the university was the central point of what should be the social elite, leading and inspiring the society round about."3

${ }^{3}$ Steven Langdon, “Bissell As High Priest," Saturday Night, September, 1971, pp. 23-26. 
In intensely egalitarian times responses to any suggestion or hint of elitism tend to be overdrawn and misinterpreted. Bissell, always sensitive to issues whether fully developed or incipient, recognized that some of his ideas were elitist or, at least, were susceptible to being interpreted as such. In one of his most frank speeches he addressed the matter of elitism in university admissions head-on:

I believe then, and here I am speaking as an educator, and not as a prophet, that liberal education should be more selective in its admissions policies. Canada should resist the American tendency to make the university into a forcing house for social equality, which is what the programs of open admissions mean. We should resist just as strongly the tendency to make liberal education a substitute for unemployment welfare, a tendency that is already beginning to appear in this country. What I am saying has nothing to do with Elitism, a liberal word, that connotes selection according to some irrelevant criteria, - wealth, class, or political views. What I am recommending is democracy, unsentimentalized and untainted.

What Bissell was recommending was that admission to the university be based on intellectual and scholastic criteria alone. This needs to be emphasized because if it were not clearly taken into account Bissell's comment about democracy could easily be interpreted to suggest a kind of Darwinism. His rejection of open admissions programs is not without notable significance. Assuming that Bissell was familiar with the basic arguments for open admissions (and given that Bissell was a thorough and scholarly administrator and that he spent a year in an American university at the time when the debate about open admissions had begun to intensify there, such an assumption is reasonable), this statement implies rather definitely that he did not believe that the university was an instrument by which social privilege was distributed - at least, not in Canada.

Bissell's conception of criteria for admission to university was based not only on aptitude and achievement, but also on attitude. For Bissell, high levels of achievement in secondary school represented sufficient aptitude for university studies; from a practical standpoint, achievement and aptitude were one and the same as a criterion for admission to university. From the moment he became president of the University of Toronto he left no doubt that only the best students would be permitted to enroll there. "We are opening our doors only to those who by right of intellectual achievement have a warrant to enter them."

But Bissell would have it that more than ability and achievement be required for admission; the will and desire to learn also would be required of the university matriculant. He made this point explicitly. "Going to university should mean a careful, deliberate decision on the part of the individual. It is not a natural and inalienable right of adulthood, like the vote and marriage." The student seeking admission to the great university must be not only able, but also willing to meet the university's standards for scholarship and excellence.

In his opinions and policies about university admissions requirements, Bissell was concerned with more than standards at the point of entrance and the interests of the university. The ramifications of admissions policies went beyond the university campus and classroom. Speaking in regard to the ramifications, Bissell argued that "there must 
always be concern lest accessibility turn into a super highway that leads to an intellectual wasteland."

In the case of matters outside of the university, Bissell had two concerns. These were for the interests of the individual and of the society. He unquestionably had the interests of the student in mind when he made these remarks:

Certainly it is clear that here in Canada we cannot accept the intellectual Darwinism that characterizes so much of European higher education whereby the slightly unfit are ruthlessly sacrificed and denied higher education. At the same time, it would be fatal if we allowed ourselves to fall into the soft democratic fallacy that since there should be no invidious distinction between the superior and the average student, then we should deny to the superior student the right to have specialized studies.

From this quotation two conlusions may be made. In advocating that access to the university be democratic, Bissell was not suggesting that only the fittest would be accommodated and served. One may also conclude that Bissell took into account the interests of students who were not of the highest calibre as well as those who were.

Bissell's comments and suggestions made at the time when the proper role and form of the soon-to-be-founded Colleges of Applied Arts and Technology were being discussed further reveal his concern for society. Bissell believed and argued strongly that in founding the CAAT's, Ontario should not establish institutions which duplicated or overlapped university programs or purposes. He did not believe that the university should be made to "carry the burden that belongs to other kinds of institutions." 4

His idea about the proper division between the university and the CAAT's seems essentially to be Platonic. Were society to provide appropriate opportunities, individuals would take advantage of those opportunities in whatever fashion best suited their natural self-interests; this, in turn, would benefit society, for its resources thus would be efficiently and fairly distributed and used. Bissell described the relationship between the university and the CAAT's especially well in these comments:

In the first place, the issue is not a simple choice between full accessibility and elitism. It is a question of the distribution of our resources in accordance with both personal and national needs. Above all, it is not a conflict between science and technology on the one side and the humanities and social sciences on the other. In whatever scheme is adopted, the humanities and social sciences will play an important role. But I suggest that there is no quicker way of debasing the study of the social sciences and the humanities than to turn them into a sort of universal deodorant.

Thus, while Bissell may have been an elitist in some ways, he was not one in the sense that he would have looked after only the interests of the university and the intellectual elite to the detriment or subordination of all other interests.

So far we have discussed what Claude Bissell thought university students should be; now we shall turn our attentions to what he thought they should do once they were

4Warren Gerard, “Mr. Big Takes A Breather," The Globe Magazine, June 24, 1967, p. 11. 
admitted to the university. In analysing the first characteristic of the great university as defined by Bissell, we recognized what he considered to be the proper curricular focus of the university. The curriculum, of course, describes much - but not all - of what the faculty and students do.

Bissell did not equivocate in describing what it was that the student was to do in the university. The mandate was clear. In 1966 he told newly enrolling students, "Your first and most important milieu will consist of your studies, and unless you pursue them diligently, enthusiastically, and adventurously, you have no right to be here."

Although, as we observed earlier in this discussion, Bissell did not believe that the genuine university subjects could or should be placed in rank order or otherwise separated from one another, he strongly favored the honour system by which individual course programmes focussed on one subject in depth. He was a product of the honour system himself. One suspects that if it had been within Claude Bissell's power to create the ideal university, he would have had the honour system prevail. Bissell was eloquent in espousing the honour system and criticizing alternatives to it. In one of his best-known speeches, he encouraged undergraduates to be, as the title of the address advised, "angular, not spherical."

During your university days you should emphasize concentration and intensity; you should not be in the least afraid of being angular or lop-sided. If you are possessed of an idea, it will in a sense create the pattern of your whole living, and enable you to move with conviction and authority amid the complexities of your university life. Even in curricular matters I distrust the principle of distribution, the idea that every university student should be exposed to the whole spectrum of knowledge, in what seems to me the naive belief that a university degree is the end and not the beginning of a genuine intellectual pilgrimage. If you have intensity of purpose and concentration, you will develop the confidence and sureness of touch that come from really mastering a subject, and you will be driven by your own intellectual curiosity into areas adjacent to your own.

This quotation explains well what Bissell thought were the advantages and benefits of the honour system. On the other hand, he did not see alternatives to the honour system as being merely inferior or benign; some had negative implications. In referring to curricular revisions and general education programs which were proposed in the 1950's, Bissell warned:

It will produce what Newman referred to as a "barren mockery of knowledge"; it will turn out graduates who can carry on a cocktail party conversation, but not conversation in depth; fashionable bohemians who can recognize the contours of an idea, but who are incapable of coming to grips with it. The kind of intellectual I have been commending has, despite his range and versatility, a firm base in his mastery of one major discipline; and it is from this position that he moves out into broader fields. If the university is going to foster him, then it must make sure that the student explores one area intensively and thoroughly, and that forays outward are determined by the intrinsic demands of the major subject, and not by a theoretical concept of what every bright young man should know. 
These two statements explain on the one hand why the student should pursue an honour course and, on the other, the inadequacies and potential pitfalls of general education programs. Although both are tangential to it, neither really describes Bissell's understanding of what the honour system was or how it related to the basic concepts of the university. What, then, is this understanding? He offered a clear statement of his position in his installation address at the University of Toronto.

This [the honour course] road to liberal education involves several assumptions. The first is that the university is not simply an extension of the secondary school. It involves a leap, a qualitative change, and demands that the student cease to be a passive absorber and become an active learner. The second assumption is that undergraduate study is not a series of credits to be added up and eventually cashed in for a degree; rather, it is a unified pursuit of knowledge. It is not an activity confined to occasional periods between social events and to a brief tortured week or so in the spring; rather it is an intellectual passion that should permeate all of a student's activities. I would willingly admit that the honour principle may not be adapted to all good students, and that it is subject to abuses. But I would still profess my faith in it as the finest instrument of liberal education, and I would hope that it would always be that. It does not lead to dullness, it leads to intensity and depth. It does not produce unimaginative specialists, it produces highly trained minds that can adapt themselves to various intellectual milieux.

An interim summary of Bissell's idea of the great university being one which sought and maintained a balance between undergraduate and graduate studies would include these notations: undergraduate students must be highly qualified in both achievement and attitude, but in intellectual achievement and attitude only insofar as admissions requirements are concerned; the honour system (or an arrangement like it in terms of concentration) is the preferred curricular arrangement; and the university's role should be clearly circumscribed and should not be duplicated elsewhere.

As with any concept of balance, equilibrium requires a mass on both sides of the fulcrum, thus our attention now will turn to graduate studies. To begin, we shall recall that Bissell's definition of scholarship was rooted firmly in the research function of the university and that "the transmission of knowledge by teaching and the dissemination and advancement of knowledge by scholarship," were, in his opinion, "the basic function of the university." Thus, a university can hardly be considered great or ideal if it is without a flourishing graduate program.

Despite the fundamental necessity of graduate level programs to a university's fulfilment of Bissell's idea of greatness, and despite the primary emphasis which he placed on scholarship, he would not condone excellence being compromised in the pursuit of either. At the time he assumed the presidency of Carleton, that institution was just beginning to achieve genuine university status and, as one consequence, the desire to leap eagerly into the expansion of graduate programs was strong. Yet Bissell counselled for caution and prudence:

... nothing undermines an academic currency more swiftly and more surely than the awarding of graduate degrees that are not taken seriously by other universities. At 
the same time, however, it is equally dangerous not to begin some graduate work as soon as possible. It is easy to push off graduate work into some distant and affluent future. In the meantime, the staff thinks of itself as concerned only with undergraduate needs, and loses its interest in research. Not only is graduate work thus inhibited, but the quality of the undergraduate teaching deteriorates.

This represents another example of Bissell's sensitivity to forces within the university working in partial opposition to one another, of the care which he took to understand how the forces were inter-related, and how they might be beneficially synchronized. Certainly graduate and undergraduate programs were to be pursued, but not headlong and not without some recognition of how they might be reciprocally related.

This balance could be upset also by forces outside of the university. Bissell has observed - and it is an especially keen observation - that relations between types of institutions could affect balances within the university. For example, were a balance not struck between the CAAT's and the universities, Bissell argued, the balance between undergraduate and graduate programs in the university would be upset. Although research often is regarded as the factor which most diminishes the attention given to teaching in the university, Bissell insightfully pointed out that inter-institutional imbalance also may be a factor. He explained that in systems of higher education which offer the first two years of the undergraduate curriculum in junior colleges as well as in the university, one result is that:

The university develops a casual attitude to the freshman and sophomore. Undergraduate work is compressed both from above by the pull of research, and from below by the pull of another institution .... The inevitable result [of junior colleges paralleling universities], I am convinced, will be the weakening of undergraduate work and, therefore, the weakening of the university.

It is evident from the foregoing that Bissell's ideas about the balance between graduate and undergraduate programs were subtle and complex. Especially interesting are his recognition and description of the factors controlling and influencing this balance. His sense of organizational and inter-organizational behaviour is remarkable.

The quality and role of the teacher is an essential ingredient in undergraduate programs and, given some of Bissell's ideas, in graduate programs. In fact, teaching represents a dynamic link between graduate and undergraduate studies in the university as Bissell saw it and establishes clearly his understanding of the bond between the two as being cohesive rather than adhesive. "The truth is," he said, "that research and teaching go hand-in-hand, and a university that has only the one and not the other is bound to be an inferior university."

Viewed in one perspective, the balance between graduate and undergraduate studies is embodied in the teacher. Bissell assumed this perspective and, having done so, once observed that:

Teaching and research have never been in opposition to each other; indeed, the university teacher is essentially a scholar in action. Teaching at the university level 
is not a technique, or even, except in rare instances, an art, but rather the infection of the student with the virus of intellectual curiosity. What this new complex world calls for is a greater flexibility in the determination of the role of each member of the staff. Teaching loads must be made to vary in accordance with the research responsibilities of the scholar and his own ease in working with students.

Scholarship, thus, is the primary activity of the university and the teacher is "a scholar in action." It seems that Bissell would not have conceded that a person could truly be a university teacher without first being a scholar. However, although there might - and, perhaps, should - be variances among individuals' teaching and research responsibilities, the university must insist that scholars do teach. Upon his return from a sabbatical at Harvard, Bissell reported that he was returning "with the conviction that the real action of the university is in the classroom." By the same token, Bissell foresaw weaknesses in teaching without research.

Before summarizing the balances between graduate and undergraduate studies as a hallmark of the great university, a specific comment about Bissell's attitude towards the status of part-time studies merits some mention. Having been the president of Carleton, a university which offered a substantial number of part-time and evening programs, Bissell's experience with this variety of higher education was first-hand. While at Carleton he predicted (his foresight was proved accurate in time) that this sector of higher education would become more and more active and expansive. Despite this prediction, Bissell apparently did not regard part-time studies as being central to the basic functions and balances of the university at either the graduate or undergraduate level. He explained that the university welcomed part-time students and was "constantly looking for ways to bind them more securely to the University. But the University exists primarily for the student who is able to devote his full time to his studies, and we are determined to keep it so."

We may conclude at this juncture that the great university as Claude Bissell defined it would maintain a careful and deliberate balance between graduate and undergraduate programs. More significant is that the forces and interrelationships upon which this balance rests are complex and subtle. And, finally, the scholar-teacher is the dynamic link between the graduate and undergraduate programs. Bissell himself has provided a fine summation of all three points:

The continued survival and strengthening of the University is ultimately justified by its success in nourishing gifted teachers and scholars. On this all else depends: the welfare of students, the spread and growth of knowledge, the effectiveness of the University as social critic, the sense of institutional well-being.

The third characteristic of the great university as envisioned by Claude Bissell also may be expressed in terms of balance. Furthermore, it is very closely related to - indeed, it partly overlaps - the second. The great university, Bissell said, "maintains a balance between its long-range goals and its short-range obligations, or between its responsibility to pure scholarship and its responsibility to the society of which it is a part." The matter 
of research already has been discussed in terms of what it is and where it fits into the university scheme. Also, in discussing the first characteristic of the great university, we noted that Bissell accepted utility of university studies as a formative factor in the definition of the university. Finally, we have come to understand the meaning of pure scholarship in Bissell's lexicon for the great university. Because scholarship is the foundation of the university, the following discussion will take the shape of an examination and definition of the relationship between the university (scholarship) and society. This relationship probably is more complex and problematic than any other aspect of the university. Furthermore, the interface between the university and society is highly variegated; it may be expressed in terms of university-government relations, of the university vis-à-vis the economy, of national identity, or of societal and institutional tradition. In the last case, the viewpoints of the university and society may be very different.

Bissell understood and could explain the perspective from which society viewed the university and that from which the university viewed itself. In explaining the viewpoint of society, Bissell noted that the nature of the university produced much of society's attitude towards the university.

Society has never had complete confidence in the university, and this is both necessary and healthy. The university is a special society made up of people who are concerned with common goals and cut off, in various ways, from the wider society. By its very nature, then, the university is bound to arouse a considerable amount of suspicion, particularly from those outside who have never been members of its community.

Thus, while contemporary opinion about accountability implies that suspicion of the university by society should be eradicated and replaced by as much confidence as possible, Bissell argues that this suspicion is "necessary and healthy."

Although he accepted the concept of utility in justifying and directing the university, Bissell never accepted the subordination of the university to society or the state. Instead, he saw the relationship between the university and the state as being a symbiotic one between two autonomous bodies, each with its own identity. Interdependence limited both parties to some extent and neither could exist without the other. Both were primary institutions in society.

Bissell maintained that the university was especially important to Canadian society. "The fact is," he said in an address at McGill, "that no country in the world depends more than Canada does upon trained intelligence and systematic research for its full development." It seems that Bissell considered the university not to be universal in its identity and, as a corollary, in its ideal. The specific society in which the university was located determined at least part of the university's role and identity. He believed, for example, that the university had an essential role to play in the development and identification of a national culture. Such a role for the university would exist only in a society which was - or, believed that it was - without a culture and was seeking to develop or discover one.

The nature of society affected the university's identity in other ways. Bissell observed that the university may itself change relatively little, but changes in the society of which 
the university is a part may imbue the university with new roles and powers. Clear examples of such a phenomenon were the impacts which Bissell foresaw on the university as a result of society's shifting from an industrial to a post-industrial economy. (Bissell apparently embraced most of the ideas of John Kenneth Galbraith and Daniel Bell in this regard.) The university, he thought, would become more dominant in society as the demand for new information and information centres grew. Such growth would be expected were a society moving into the post-industrial stage. The traditional role of the university as an intellectual bastion might actually render it more contemporary rather than obsolete under such conditions, for as Bissell saw it the university's

... insistence on an intellectual goal, far from removing it from society and diminishing its impact, as it might have done formerly, gives it a position today of extraordinary centrality and power. For today the amassing of new knowledge, its analysis, storage, and retrieval has become the basis of growth; and the electronic age is endowing the natural energy of the human brain with power of a nuclear explosiveness.

The point to be made here is not so much that the post-industrial state is as Bissell described it or whether or not its impact on the university would have the results which he predicted, but that the condition of society could alter the role of the university. Thus, when one speaks of an ideal balance between the university's responsibility to pure scholarship and its obligation to society, one must recognize that this balance, if it can be achieved at all, is an ever-changing one and requires continual monitoring and adjustment. It is for this reason that Bissell's third characteristic of the great university is the most difficult to isolate and identify. Bissell was not unaware of this difficulty and, it seems, did not believe that the proper balance was necessarily one which resulted in a perfect equilibrium. Like public suspicion of the university, the absence of a perfect equilibrium was not always a negative reflection on the university ideal. In his installation address at Carleton Bissell elaborated on this point:

Any university is a repository of an ancient and honourable tradition that operates as a corrective to transient popular impulses. The university should not be disturbed if, occasionally, it seems to be out of tune with the times, if, indeed, it is an irritant rather than a consoler.

Bissell believed firmly that the university's responses to societal changes, conditions, and subsequent demands need not always be perfect reflections of those conditions or demands. He talked about the university's response in terms of a realignment:

The university, then, is concerned with its realignment in society. The movement to the centre has meant the breakdown of old barriers and has brought the University closer to the concerns of all members of society. This accounts for the increasing insistence by society that the University accommodate itself to accepted political structures and that it welcome detailed and uninhibited public scrutiny of its actions. I believe that movement into the centre must inevitably be accompanied by a move- 
ment into the spotlight, embarrassing and distracting though that may be to one accustomed to the discreet shadows. But I do not think that the University should, on this account, give up the traditional concept of separateness. It should not permit itself to be transformed into a business corporation or a county council or a nonviolent co-ordinating committee. Its expanded social involvement simply means that it must accustom itself to living in two worlds with double responsibility and double jeopardy.

One conclusion to be made from this quotation is that the ideal balance between pure scholarship and community service is not one which can be struck and maintained in a static position. Instead, the maintenance of the balance must be cybernetic in the sense that the balance can only be controlled by continous feedback between the university and society.

There are certain aspects of the relationship between the university and society which Bissell thought are constant in that they always are present in the relationship, although in varying degrees. This seems to be the attitude which he took towards the role of government apropos of the university. He made it quite clear that he thought that government interest was inevitable and that the degree of that interest was not governed by the extent to which the government allocated resources to the university. Indeed, government interest in the university was natural and, thus, legitimate. Bissell explained that the reason for this was that the "university is too demanding in its needs and too central in its functions to depend mainly on private support...."

But a simple and practical concern for resource allocation was not the only reason which Bissell offered for the virtually permanent interest of the government in the university. With great insight and conceptualization Bissell explained that in some ways governments and universities were performing very similar, if not identical, roles.

... the universities are, whether they want to be or not, closely associated with the role of government itself. Governments are becoming research organizations constantly searching for the most authoritative information and the most convincing theories upon which to base their policy. They thereby become, along with the universities, employers of scholars specially trained in particular fields, and increasingly they make use of universities as research resources. At one and the same time, then, universities are emphasizing their independence of government control and are growing closer to government in interests and in employment of key personnel. What this means is that governments and universities must be partners in the making of major decisions with respect to the development of higher education. But they must at the same time be partners who are conscious of their separate identities and their separate responsibilities.

This statement summarizes well two major components of Bissell's idea of the relations between the university and society. The first is that government presence is a constant factor in the relationship and that this presence is not discretionary either on the part of society or the university. The second is that certain powers and autonomy are reserved by the university; control of the relationship is bilateral. Note that it is the 
relationship that is the object of control and not one party or the other.

What, then, does Bissell advocate that the university do to achieve and maintain the balance between scholarship and community service which his description of the great university requires?

First, the university must recognize and define those freedoms which are essential to its function and identity. According to Bissell these freedoms are

... the freedom to determine who shall be taught, the freedom to determine what shall be taught, ... the freedom to determine who shall teach . . . the freedom to distribute its financial resources as it sees fit.

These freedoms should not be compromised or surrendered. Given the three characteristics of Bissell's great university so far discussed, it is evident that without these freedoms no university is likely to become great.

Second, the university should deliberately and actively seek to husband and nurture the relationship between government and the university. In doing so, the university should not assume a defensive or hostile posture. Bissell advocated instead that the university "distinguish between government concern and government control. ... The question is not one of organizing stubborn resistance to government, but rather of developing the means to carry on a vigorous dialogue with government."

Third, the university should consider that government interest might sometimes be constructive and beneficial. For example, Bissell thought that in Canada a "direct federal interest will mean a more bracing atmosphere, less constricted and introverted, more receptive to international ideas and needs."

Finally, and perhaps most importantly, the great university would understand the dynamics of the relationship between itself and society. Control of this relationship is essentially cybernetic and, thus, the university should tolerate and accept continual shifts in balance between its responsibilities to scholarship and to public service. Also, because of the nature of the relationship, the great university would not isolate or insulate itself in any way which would diminish or interrupt the flow of information between itself and society. The operational mandate of Bissell's description of the relationship between the university and society is that because the two are interdependent, the university has the responsibility and authority to govern itself and to decide if and how it will respond to societal demands. The decision about how to respond to such demands is a crucial one for the university, for as Bissell warned:

... community need, or community service, is in higher education a dangerous catchphrase. "There are," wrote George Eliot, "certain generalities that eat out the heart of morality;" and there are certain generalities that can undermine the work of the university. Among these is the assertion that the university should accept any vigorously expressed community need as the warrant for educational policies. This can lead to dissipation of effort, to weakening of standards, to the transmutation of the university into - and here I quote from Robert Hutchins - "a folk institution, reflecting the whims, no matter how frivolous or temporary, of those whose support it is hoped to gain." In other words, the university loses its independence; and loss of 
independence by surrender to every articulate community demand. . . is the most fatal kind of subservience.

By excercising its legitimate "powers of initiative, innovation, and independent action," the great university would serve its own interests and those of society. Bissell maintained that without freedom and autonomy the university could not meet its obligations to society. Thus, the freedoms of the university are not to be seen as factors located on only one side of the fulcrum on which scholarship and community service are to be balanced. Instead, it is the university which must exercise these freedoms in order to strike and maintain the appropriate balance or, to be more accurate in light of the changing nature of the relationship, balances. Furthermore, the university should use its autonomy to participate in a dialogue with government to ascertain appropriate balances, thus inviting rather than rebuffing government concern.

In a descriptive sense separating scholarship and public service is not especially complex or problematic. However, when research alone is considered, the process of separation takes on a perplexing dimension, for, of the academic enterprises within the university, research is the one of which society tends to take the most utilitarian view and of which it is most suspicious. Furthermore, as already has been noted, Bissell saw research as being an activity in which government and the university were mutually engaged, thus drawing the two more closely to one another. Thus, it is important that in concluding our discussion we direct our attention to Bissell's attitudes towards research within the context of the balance between pure scholarship and public service.

Bissell was very definite in his understanding of what research was and how it should be conducted in the university.

In research there are a number of clear rules, which a university violates only at the risk of confusing its function. It is clear, for instance, that classified research, research that enjoins secrecy upon the scholar and forbids publication of his results, should not be undertaken except as a matter of grave national emergency. No scholar can hoard the results of his own work; he lives and prospers only as others share in the excitement and satisfaction of his discoveries. Another general rule is that research should originate with the scholar; it must be the outcome of his own work; and follow inevitably from what he has already done. Research that is imposed upon him from outside is not really research at all; it is just a form of academic prostitution. A scholar should not confuse the collection of data with research, no matter how worthy the purpose or how benevolent the sponsoring organization. Above all, he should avoid the elaborate documentation of the obvious, the ponderous proof of the self-evident...

Much of this description of research would have its application within the university, but some aspects add clarity to the roles created by the juxtaposition of government and university. It is clear that Bissell saw the animating spirit of research flowing from within the university and, indeed, within the individual scholar; society or government, therefore, had no influence over the seminal origins of research. Research could not be imposed upon the scholar. Society and government could not and should not regard the research function of the university as a service available on or responsive to demand.

On the other hand, the scholar is obligated to make the results of his or her research 
available to society. Bissell seems to have felt that society had a legitimate claim on the end-product of university research, although not on the research process itself.

Finally, the nature of society and of knowledge as seen by Bissell limited the social alternatives to university research and invested the university with fundamental and monopolistic power. Research was not only a proper and basic role for the university. Bissell once asserted that the university's research activity was a social necessity; "they [the universities] are the only places where the new knowledge and new insights that emerge from academic research can be created ..."

This last comment about the nature of research has a dual significance for our discussion. On the one hand it makes clear Bissell's opinion that the research function of the university is not a social artifact; it is a social necessity. This is the justification for the university's having the authority and autonomy to control its scholarly activities. This authority is not a socially (or governmentally) designated power; it is a power which accrues naturally to the university.

On the other hand, the significance applies more broadly to the entire matter of balance between scholarship and public service as prescribed by Bissell. Unlike the other balances in the great university, this balance is not static and is in part beyond the control of either the university or society. Furthermore, whatever control is possible is achieved by a continual process involving the university and the government as partners and not by a unilateral and singular executive authority. The independence of the university is an essential means - not an end - by which the university may perform its service to the community and fulfill its public obligations. The independence of the university, thus, benefits both parties.

Finally, in a time when universities were coming under more and more public criticism and were facing greater and greater demands for public accountability and relevance, and the delicate balance between scholarship and public service was thus being threatened, Bissell stood firm in his creed of autonomy for the university.

One must remember that the university's responsibility is to the world of knowledge, and that this responsibility transcends even the desires of students.

The emergence of the university of strength and purpose will depend upon the recognition by the university of its peculiar position, and on the willingness of its leaders to make clear and unequivocal claims.

If Bissell had to choose between the long-range scholarly goals of the university and immediate public needs, it seems that he would have chosen the former unquestionably.

The fourth and final characteristic of the great university is that it would create and sustain a sense of community. Bissell believed that of the four characteristics of the great university maintenance of a sense of community was "the hardest to define and the most difficult to realize."

Bissell's idea of a university community encompassed more than a simple notion of a congenial and comfortable environment. In some ways, the community was part of the educational process itself. In others ways, it influenced scholarship. Finally, it could be defined in either organizational or attitudinal terms. 
One of the greatest dangers of what he called the "new radicalism" in the 1960's was its anti-institutional bias. This bias challenged the concept of community within the university. Bissell was staunchly opposed to anti-institutional notions and urged that the university "take the steps necessary to prevent any of them from enveloping the university community." Given his strong reaction to the anti-institutional ideas of the 1960 's, it is apparent that Bissell did perceive of the university as an institution. Furthermore, he had a clear conception of what sort of institution it was. He described the university as being:

... an organization of human beings with a definite structure, where there is division amongst its members according to function, where there are ... hierarchical arrangements. The institution thus has its own sense of coherence, its own inner identity and sense of autonomy. It also has a sense of mission, of marshalling energies and talents to achieve a goal, or goals.

Despite the complexity of this organizational description, Bissell believed that the best university environment was an informal one. Informality, he claimed, would be a source of strength to the university. His ideas about and respect for an informal university environment seem to have been strengthened during his sabbatical year at Harvard, the environment of which impressed him very favorably.

Just as he favored organizational informality, he favored smallness of scale. The two were combined in the college arrangement. What were the advantages of the college system? There was, according to Bissell, a fundamental one: the college, he said, "provides the best conditions for the best kind of scholarship." These conditions made the college "a place of serenity and productive leisure, and it is, above all, a place where the individual scholar is king."

Although he favored colleges and other small scale units, Bissell did not believe that the multiversity was incapable of maintaining conditions within it which were compatible with a sense of community.

There is much nonsense today about the inevitable development of the university into an ivy-covered supermarket or factory .... The heavy implication is that of facelessness and mechanization. The truth is that the complex university heightens individual self-consciousness. It concentrates social and intellectual forces so that they beat directly and intensively on the student and make it possible as never before for him to live in an individual world.

The juxtaposition of these comments about the college and the multiversity suggests that Bissell was equivocal about what the nature of the community in the great university was or should be. Given his own background and experience, Bissell was accustomed to the collegiate arrangement at the University of Toronto. And this seems for him to have been the ideal organizational foundation for the university community. The following quotation summarizes well Bissell's ideas about why a sense of community was necessary, how environment and process were related, and what organizational arrangements best furthered a sense of community: 
These ... qualities [of the intellectual] can only be developed in a society where there is an easy give-and-take between individuals, where social equality goes along with a frank recognition of intellectual difference, where the educational process is continuous both within and outside the laboratory and the classroom. This is the ancient and glorious tradition of the university as a community of scholars. It is a tradition that the large unitary university can no longer support .... But the solution lies, not in the creation of more and more small centres of higher learning, but in the recreation of the large universities in terms of small units, where teaching, research, and good talk and debate can be united in a human setting. For the intellectual cannot live by the mind alone; he needs the warm corrective of the human community.

Given the articulateness of this quotation, there are only a few more notations that need be made to complete our understanding of the community of the great university.

There was, in Bissell's judgment, an educational function served by the university community. In the first place, Bissell maintained that although the university could not produce geniuses, it could provide an environment or - if you will - an incubator, which enabled and encouraged persons to realize their greatest potentialities.

It was Bissell's contention that certain organizational and operational functions of the university were dependent on the maintenance of a sense of community. Among these functions were seminars, residential colleges, and a diverse student body. The reason for this dependence was that all of them assumed the educational value of communication and the community made communication possible. According the Bissell:

... the really vital means of private communication is the discussion or dialogue, the direct communication of mind with mind in conversation and argument, in which wit and awareness are sharpened and ideas fly about like sparks from flint and steel.

There can be little question that ideas and their communication were at the heart of the ideal university community as defined by Bissell. In fact, Bissell once argued that the only community possible in a university was a community of ideas.

The university environment, as Bissell saw it, could affect the members of the community through tradition as well as through education and communication. This effect was possible because of the organic nature of the university. This is Bissell's description of the impact of tradition within the university community:

The great universities create their own traditions, which do not depend on the ordinary business of instruction. A university has, as it were, its own cultural environment, that acts upon staff and students powerfully, although often indirectly. It can communicate to its students something over and above formal education, something that amounts to an attitude towards life.

In addressing questions about the balance between the university and society considerable attention was paid to matters having to do with academic freedom from an institutional viewpoint. At this point, we shall attend to questions about academic freedom from the individual's point of view. Just as Bissell espoused autonomy for the 
university, he championed academic freedom for the scholar. He did not consider academic freedom to imply any special license for the scholar. The scholar had all of the rights of any individual in society but he or she also had the obligation to advance knowledge; thus to curtail the freedom of the scholar would amount not only to a violation of the freedom of the individual, but also would constitute an abrogation of the very purposes of scholarship. What, then, are the implications for the university community of academic freedom as Bissell understood it?

Academic freedom is repellent to intolerance and authoritarianism, but not to personal conviction. We can all recall inspiring teachers whose words were aglow with evangelical fire. The university does not consist, then, of open minds unstained by conviction, through which blow ceaselessly and innocuously the winds of speculation and doctrine; academic freedom is not synonymous with cool disengagement. The concept of freedom as it flourishes here [the University of Toronto] owes much to the two major traditions - the secular tradition of the usefulness of all knowledge, and the religious tradition of the redemptive power of truth.

Academic freedom, thus, animates and energizes the flow and volume of communication which is utterly essential to the sense of community within the university, especially the great university.

The university's sense of community, as we now understand Bissell's conception of it, is a complex and multi-dimensional environment. It is more than simply the medium in which the components of the university function; instead, it is in some ways part of the university process itself. Bissell's description of the community within the great university includes organizational, educational, governmental, social, and dimensional characteristics.

In bringing our discussion to a close we shall recall the four characteristics of the great university as envisioned by Claude Bissell. First, the great university was to be a "stronghold of scholarship" in the arts and sciences, with specific descriptions of the relevant subjects. Graduate and undergraduate programs were to be of equally high standards and development. The great university would maintain a balance between its commitments to pure scholarship and its obligations to public service. And, finally, the great university would carefully husband a sense of community within it.

Where there were value judgments to be made in establishing specifications for the great university, Bissell always favored the excellent, the scholarly, the intellectual, the independent, and the primary roles for the university. In considering the alternatives available in prescribing for the great university, Bissell often saw the problem and state of the university in terms of conflicting tensions:

The university, like all basic social institutions, is conservative to the extent that it must always assess its present role in the light of its past convictions and practices. The university should not be reactionary, in the sense of being resistant automatically 
to anything which seems to deviate from accustomed practice. But it must always be concerned that the new is organically related to the old. Unless this interrelation between the past and the present is maintained, the university may find itself wandering in areas where it is confused and ineffective. For the university there is a constant tension between its traditional role and pressures from the society in which it lives.

Thus, he often explained the nature of the university in terms of balances. Sometimes these balances are such that once struck they can be maintained and defined: others are precarious at best and demand constant monitoring and readjustment.

We asked at the outset whether or not Claude Bissell conceived of or believed in an ideal of the university. A reasonable and fair conclusion is that he believed that an ideal should be sought, but that existing - whether in fact or in theory - universities were not ideal. Indeed, given Bissell's description of the fundamental tensions in the university between its traditions and its contemporary responsibilities, any solution to the question of what is the ideal university could only be a proximate one.

The great university, although probably never realized in any one institution, is a creation of the past and the present and is basically realistic in its conceptualization. The ideal university, on the other hand, exists only in the future and is a theoretical conception. Contemporary and traditional ideas of the university, thus, are processes, the purpose of which is to discover or create the ideal university. The conclusion to be made is that Bissell's great university is a means for discovering the ideal university.

Bissell would not have considered the great university to be the ideal university; penultimate, perhaps, but not the ideal. The justification of the great university, thus, is to be found in its promise.

In what may be one of Claude Bissell's most eloquent statements about the university, he suggested that the very nature of the great university is, at least in part, undefined, constantly changing, imperfect, and experimental. Thus, he called for an emotional, as well as intellectual, commitment to the university:

Yet if an institution is not loved by those who know it best, it cannot long survive. That is particularly true of a university, for it is, of all man-made institutions, an act of faith, a perpetual experiment, a search for the ideal.

All other references and quotations have been taken directly from the articles, essays, speeches, and reports of Claude Bissell. All unpublished MSS to which reference was made are in the files of the Higher Education Group, University of Toronto. A longer version of this essay with detailed and complete footnotes is available from the author. 